\title{
LET'S TALK EASILY ABOUT STEREOCHEMISTRY: A HOMEMADE EXPERIMENT TO UNDERGRADUATE STUDENTS UNDER SOCIAL ISOLATION
}

\author{
Tiago Lima da Silva ${ }^{\text {, Jose C. Barros }}{ }^{\text {, Pamella Moreira Monte }}$ \\ a Universidade Federal do Rio de Janeiro, Brazil
}

\begin{abstract}
Under social isolation due COVID-19 we are adapting to the new educational scenario. Taking methodologies previous developed in distance education using video conference the world is establishing a new area called technopedagogy. Stereochemistry topic in Organic Chemistry is always difficult to understand even in class-courses. The rotation of plane-polarized light is challenging to teach because it requires high level of abstraction about the mental experiment. Thus, in this work we propose the development of a tool to be used in remote way to teach stereochemistry. Thus we have made a tutorial video teaching college students to perform a hand-made experiment in stereochemistry topic. This video was nicely scored by teachers and post graduate students.
\end{abstract}

Keywords: Stereochemistry; Sugar; plane-polarized light.

\section{VAMOS FALAR CALMAMENTE SOBRE ESTEREOQUÍMICA: UM EXPERIMENTO FEITO EM CASA PARA ESTUDANTES DE GRADUAÇÃO EM ISOLAMENTO SOCIAL}

Resumo: Partindo de metodologias anteriormente desenvolvidas em educação à distância por meio de videoconferência, o mundo está estabelecendo uma nova área chamada de tecnopedagogia. O tópico de estereoquímica, em Química Orgânica, é sempre difícil de entender, mesmo nas aulas presenciais. A rotação da luz planopolarizada é difícil de ensinar porque requer alto nível de abstração sobre o experimento mental. Assim, neste trabalho propomos o desenvolvimento de uma ferramenta a ser utilizada de forma remota no ensino de estereoquímica. Assim, fizemos um vídeo tutorial ensinando estudantes universitários a realizar um experimento feito à mão no tópico de estereoquímica. Este vídeo foi muito bem pontuado por professores e alunos de pós-graduação.

Palavras-chave: Estereoquímica; Açúcar; luz plano-polarizada. 


\section{INTRODUCTION}

We are going through a pandemic situation in which our way of life is changed day by day and we need to adapt to a new scenario using the tools provided by new technologies [1]. Previously, a new industrial revolution began to obscure the relationship between the physical, the biological and the virtual and emerged during the third industrial revolution [1,2]. Nowadays, schools, universities and educational centers are dangerous places due to the risk of contamination by the new coronavirus COVID-19. Due to the imperative of maintain social distance, to reduce new deaths by COVID-19, it is mandatory to create efficient educational methodologies using technologies brought about by Industry 4.0.

Stereochemistry is an important branch in organic chemistry to understand biological topics such as molecular recognizing, DNA and smelling; in chemistry is important for students to understand asymmetric catalysis and others asymmetric molecular phenomenon [3]; in bioengineering is important for engineers to understand the bioprocess and thus to increase the production of biofuels like ethanol, for example. Furthermore, the knowledge about stereochemistry allows to identify purity in sugar industry which is an important factor required by consumer in the whole world. For instance, the rotation of plane-polarized light is a physical constant and can be used as reference of purity to a several chiral compounds [3,4].

To teach stereochemistry under normal conditions is important the knowledge about chemical structure, relative and absolute configuration, and also, last but not least important, representation in three-dimension over two-dimension paper sheet. Students are able to develop these abilities at traditional classroom under teacher support and pedagogic tool to visualize tridimensional object, such as example of the molecular model [4]. Exercises and simulations are important to settle basic concepts because they are not trivial. Even using this educational structure and all of these tools the topic of stereochemistry remains hard to learn to beginner students [5].

The ability to view molecules in three-dimensional space is critical for the organic chemist. To tag molecules as $R$ or $S$ using CIP (Cahn-Ingold-Prelog) rules indicating an absolut configuration is the second row of abilities expected by a student taking the organic chemistry course [4]. Since 1960 until now different methodologies to teach stereochemistry were created to improve the comprehension of students. In the beginning it was common to use hands as asymmetric teaching tools to tag molecules as $S$ or $R$ [4]. Currently we update our teach methodology and now we use plastic molecular model and also computers programs able to present molecules in three-dimensional details [5].

In practical classes is challenging to explain physical properties which come from chiral molecules [3-5]. The measure of rotation of light plane-polarized using a polarimeter is the main experiment to present the practical face of the chiral molecule. In Brazil we face scarce financial resources to perform these practical classes about stereochemistry. Chiral chromatography, polarimeter or any other chiral technique are not present in chemistry classes for undergraduate students. In order to solve this obstacles it is important to propose new didactic classes using cheap material and do-yourself methodologies [3].

The world pandemic caused by COVID-19 put in check our old way of life pushing us to a new and different scenario. To keep teaching some topic such as 
stereochemistry and polarimetry, which was challenging before the pandemic, we require the use of tools present in a society where industry 4.0 and internet of things is present. Remotes Classes, virtual seminars and forums linked to educational centers are mandatories now to aid students to keep learning [1]. We have two aims in this work, the first is to produce a tutorial video using a free edition video program and the second aim is to teach college students to perform a handmade experiment about deviation of plane polarized light.

\section{METHODOLOGY}

In accordance of the world educational proposes to keep learning and stop school we take account which has already been done to improve education in distance for children and adults [2]. The solution is being Synchronous and asynchronous classes built by different movie makers programs, educational apps such as "Feed the monster" $®$ where aids kids to learn, to recognize letters and form some basics words [6]. Our methodology is divided in two parts. One of them concerns to perform the handmade experiment explained in the video and another is to create the short-movie using a moviemaker program.

Handmade experiment of rotation of plane polarized light using household cheap reagents and products. First of all, we have taken a polarizer from a watch or a calculator, sugar, light source from a cell phone, a computer as a source of polarized light, rubber band, two glasses cup and water. In hand of these materials we were able to perform an experiment similar to experienced by a polarimeter. We have noticed difference in light that went through the glass of water when the solution contains sugar. Of course, the student must be guided by supervisor in remote way to acquire the best comprehension of the topic.

The second part belongs to the current propose to teach in distance because of the social isolation. It has been chosen a free movie maker program called ApowerEdit ${ }^{\circledR}$ to produce the short movie. This short-movie is parts of a stereochemistry class in Organic Chemistry department in Universidade Federal do Rio de Janeiro. This movies belongs a short library of movies which are being produced by teacher in this university as a new attitude to produce asynchronous material to be watched by students. This is a new trend in the world; this is a new tendency toward to a new world order called techno-pedagogy. Our work was applied to a small group of eight students and 3 teachers of organic chemistry to validate the work as a simple and effective techno-pedagogic tool. Simple to understand the explanation and simple for to do experiment was the two criteria evaluated in our work.

The video is available in the google drive of our student and was not uploaded in any streaming platform yet. We are exposing this video in intranet platform inside UFRJ called AVA (Ambiente Virtual de Aprendizagem) and waiting the best replies to the video and the experiment. Then we will upload this video in popular video streaming platform.

Link to the video:

https://drive.google.com/file/d/1u91LUbhFtc4Ki5twL6jCvzqrZZ7F7e1h/view?us $\mathrm{p}=\mathrm{drivesdk}$ 


\section{RESULTS AND DISCUSSION}

The chemistry always has been taught using approximation at the world we live to understand the unseen and intangible quantum world [3-5]. To overcome any misunderstanding and misinterpretation it has been used as techno-pedagogical tool movies, apps, animation and other unusual didactics material [6]. In technopedagogy the role of the teacher is kept because it is always important to guide the student to understanding concepts today and ever.

Video-conferencing as a tool to connecting students and teachers has been used for a long time and the number of papers about this area is huge and still growing $[7,8]$. Currently are presented three types of video-conferencing for teaching in remote way: Desktop video-conferencing (DVC), Interactive Video-Conferencing (IVC), Web video-conferenging (WVC) [8]. Comparatively WVC presents low cost, better relationship to student and has showed the best results after classes. Under the light of analysis of constructivism and cognitivism has applied to WVC to identify the paradigms in education in remote way and use it after social isolation caused by COVID-19 [8]. Using the constructivism analysis WVC allow the student to experience another way of learning and improve the understanding of a topic taught. That is a very important pedagogic fact to avoid misunderstanding from a difficult topic which could be taught by analogy [8]. In another hand, in the light of cognitivism theory, the students develops a skill to dialogue with a topic in chemistry and thus find a way to solve problems related to ambiguity in knowledge [8].

In the stereochemistry topic some experiment are too difficult to visualize because they are too abstract, despite we find in literature excellent pictures and representations. In order to demonstrate the topic about physical properties from solutions containing chiral molecules we build up a video showing the rotation of plane polarized light using cheap material. According to WVC technique is a video streaming recorded and available to students during stereochemistry classes. This short-movie about stereochemistry was prepared to be watched in asynchronous way, to be watched by cell phone or others device in so many times as the students want it.

In the chemistry laboratory, in experimental class about stereochemistry it is important to identify properties from a solution containing a chiral compound. In stereochemistry is defined the concept of specific rotation which allows to measure a rotation of plane-polarized light of a solution containing a chiral compound in standard condition and also compares the values to reference literature [3-5]. The specific rotation is the quotient between observed plane polarized light over the product between concentration, at $\mathrm{g} / \mathrm{mL}$, and the path length of the cube where the light goes through (Equation 1). Specific rotation measure requires a temperature adjust and the description of the wavelength of the light used. To find the specific rotation at class requires a polarimeter, analogic or digital, but the most important to visualize is the deviation of plane polarized light.

$$
[\alpha]=\alpha \cdot[(C) \times I]^{-1}
$$


We propose a qualitative experiment to identify the influence of chiral substance in solution. We began our experiment using a chiral compound, sugar, and a universal solvent, water. Anyone can afford sugar and water to perform this experiment. The polarizer comes from an old calculator and the source of the light polarized comes from the screen in traditional laptop. Once that solution between water and sugar is prepared, we observed, qualitatively, the change in the behavior of the light when we rotate the polarizer over the laptop screen. There are no changes in polarized light when we perform, in the same way, a rotation of the cup of glass containing only water.

Considering remote classes using WVC and no opportunity to perform a lab experiment this video represent an option to discuss about the deviation of plane polarized light and stereochemistry. Based on World Economic Forum about elearning is assumed better results in retain information and less time to learn when correct techno-pedagogical methodology is applied [7]. The use of advanced technology in information allows better organization to students in your own pace and also drives the students to learn in structured way.[9]. Short movie able to be reproduced in anywhere and repeatability is important to a new industry and new world scenario $[9,10]$. Thus our work matches to new techno-pedagogical methodology and also a new world scenario [9-12].

We measure our results in qualitatively responses from our short group. After video watched it was asked about topic explained in video. Then the video was scored at understandable, not understandable or must be remade. At unanimity all participants elected maximum score to our short movie to be used as WVC. Despite the reduced numbers of participants to be relevant statically. In close future, we plan to apply our short movies in heterogeneous classes, applied by different teachers and for different courses related to chemistry. Soon we expect to produce shorter video like this in different topics in chemistry to help in our new scenario during isolation social and after.

\section{FINAL CONSIDERATIONS}

We achieve our objectives because we produced a short movie and we propose a cheap experiment to be done in safe way and also so worth in point of view of techno-pedagogic way. Furthermore, we have developed this WVC product in accordance to constructivism and cognitivism theory and it allows to be consumed by students and teachers in asynchronous way. We expect in close future to use the same methodology and expand the number of topics in chemistry and to be used to higher number of students and teachers.

\section{REFERENCES}

1 BERGMAN,M. M. World v.1, $\mathrm{n}^{0}$ 1, p. 45-48

2 ALMADA, M.I.M.; SALAS, L.M.; LAVIGNE, G. Revista Universidad y Sociedaddel Conocimiento. Vol.11. $n^{\circ} 1$, p. 91-107. 
3 BARTA, N. S.; STILLE, J.R.. Journal of Chemical Education, vol.71, n. 1, p. 20-23. 1994

4 ELIEL, E.L. Journal of Chemical Education, vol.41, n. 2, p. 73-76. 1964

5 DA SILVA JR. J.N.; UCHOA, D.E.; SOUZA LIMA, M.A. et al. Journal of Chemical Education, vol.96, n. 8 p. 1680-1685. 2019

6 MICHAL, B. Online education during COVID-19: challenging but rewarding. CGTN. China. 21 Apr 2020. Available at: <https://news.cgtn.com/news/2020-0420/Online-education-during-COVID-19-challenging-but-rewarding-PQ8FZpXr68/index.html> Accessed on: 7 Aug. 2020.

7 CATHY, L.; FARAH, L. The COVID-19 pandemic has changed education forever. This is how World Economic Forum. 29 Apr 2020. Available at: $<$ https://www.weforum.org/agenda/2020/04/coronavirus-education-global-covid19online-digital-learning/ > Accessed on: 6 Aug. 2020.

8 El KATHIB, A. S.. Videoconferencing Classes: A solution to the social distance caused by COVID-19 or a big problem? Fundação Escola de Comércio Álvarez Penteado. 16 JUN 2020.2 Available at: $<$ https://www.weforum.org/agenda/2020/04/coronavirus-education-global-covid19online-digital-learning/ > Accessed on: 5 Aug. 2020.

9 VINER, R.M.; RUSSEL, S.J.; CROCKER, H. et al The Lancet Child \& Adolescent Health. Vol. 4, n. 5. 397-404. 2020

10 FALVO, D. International Journal of Technology in Teaching and Learning. Vol. 4, n. 1, 68-77. 2008

11 AHMAED, A. International Journal of Creative Research Thoughts. Vol. 8, n. 6 p. $243-246.2020$

12 Runjan, S. The Indian Journal of Pediatrics. Vol. 87, n. 7 p. 532-536. 2020 